\title{
A hundred years later: new record of the rare Cryptotis tamensis (Soricidae: Mammalia) from Tama National Natural Park, Colombia
}

\author{
Carlos H. Cáceres Martínez \\ Aldemar A. Acevedo Rincón \\ Grupo de Investigación en Ecología y Biogeografía (GIEB), Universidad de Pamplona, Colombia. charli1391@ gmail.com \\ José F. González-Maya \\ Proyecto de Conservación de Aguas y Tierras, ProCAT Colombia/The Sierra to Sea Costa Rica \& Instituto de Ecología, \\ Universidad Nacional Autónoma de México, México DF, México.
}

The Tama Small-eared Shrew (Cryptotis tamensis), recently described and separated from C. meridensis and C. thomasi (Woodman, 2002), is one of the largest shrews in the Neotropics (Quiroga-Carmona \& Woodman, 2015). Endemic to Colombia and Venezuela, most information for the species only comes from few collected specimens (García et al., 2014), and therefore many aspects of its natural history and ecology still remains unknown. Despite its very restricted and microendemic range in the Paramo of the Tama, in bordering areas of Colombia and Venezuela in the highlands of the Tama National Natural Park (NNP) in Colombia and El Tama National Park (NP) in Venezuela (Quiroga-Carmona, 2013; García et al., 2014), the species has received little attention, and no specific studies, other than its taxonomic aspects (Woodman, 2002), have been evaluated. The species and its range is considered isolated from C. meridensis by the Táchira depression, highlighting the biogeographic importance and potential of the Tama Massif for endemicity and other phylogeographic singularities (Woodman, 2002).

To date, the few records for Colombia are located in Norte de Santander department, specifically in the "Páramo de Tamá" (Field Museum of Natural History: FMNH 18571-18572, 18608-18611, 18613-18615, 18621; Museum of Comparative Zoology, Harvard University: MCZ 21004; United State National Museum: USNM 260747) all between 2.385 and $3.329 \mathrm{~m}$ asl (Woodman, 2002; Woodman, 2008; Quiroga-Carmona \& Woodman, 2015). However, it is expected that its distribution is potentially larger, especially given the conservation status of the larger context of the type locality in Colombia (Woodman, 2008), but still, its status and all aspects of its natural history and ecology are completely unknown (Woodman, 2008). Here we present the most recent record of the Tama Small-eared Shrew for Colombia as a contribution to this poor-known species in the country.

The record of the Tama Small-eared Shrew is located within the Tama NNP, Herran and Toledo municipalities, Norte de Santander department, Colombia on the border with Venezuela. The park presents an altitudinal range between 350 and 3.450 $\mathrm{m}$ asl, and covers approximately 48.000 ha mostly composed of large areas of paramo, montane forest and tropical forest (Minambiente, 2008). Even when the park has been considered among the most important areas for biodiversity conservation in the region and Colombia (Cáceres-Martinez et al., 2016), it is also highly threatened and mostly unknown in biological terms (Cáceres-Martínez et al., 2016; Acevedo et al., 2016).

During a field trip conducted on July 24, 2014 to the Páramo de Tama, we found a well-preserved dead specimen of $C$. tamensis (Figure 1A), specifically at the Orocué sector $\left(07^{\circ} 24^{\prime} 11.7^{\prime \prime} \mathrm{N}, 72^{\circ} 26^{\prime} 29.2^{\prime \prime} \mathrm{W}\right)$ at $2.872 \mathrm{~m}$ asl, on a trail leading towards paramo, but located on a High Andean Forest patch known as Alto de Pesebre (Figure 2B). The specimen had numerous injuries in the head, most cover with a large number of ectoparasites (ticks). Both the specimen and ticks were stored in a preserving solution (alcohol 70\%, formaldehyde 30\%), for subsequent identification. The specimen was deposited and catalogued in the Mammalogy Collection of the Museo de Ciencias Naturales "José Celestino Mutis" from the Universidad de Pamplona (MCNUP-M-55). Confirmation of the species identification was supported on previous accounts and taxonomic revisions of the species (Woodman, 2002; Quiroga-Carmona \& Molinari, 2012; Quiroga-Carmona, 2013; García et al. 2014; Quiroga-Carmona \& Woodman 2015).

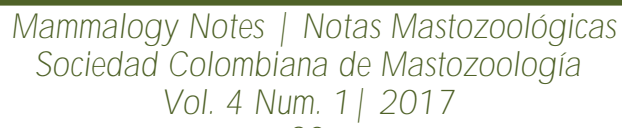




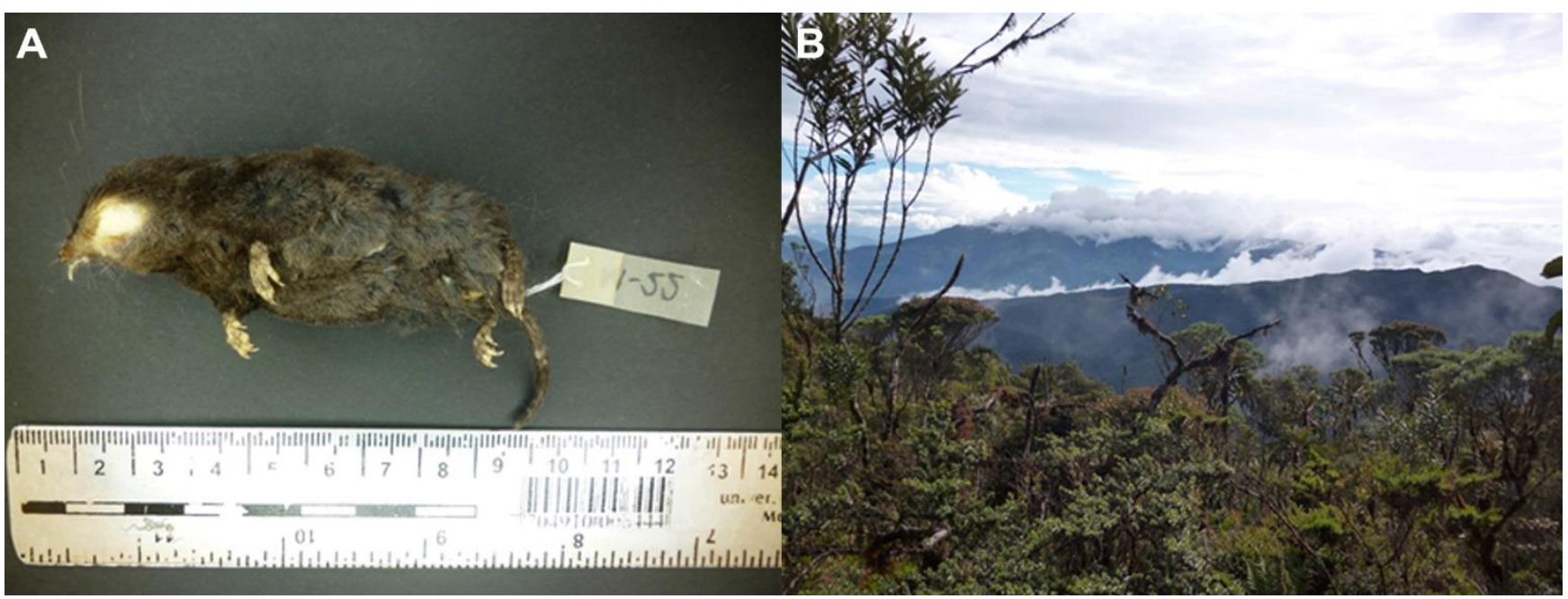

Figure 1. Preserved specimen of the most recent record of Cryptotis tamensis (A) in a High Andean forest (B), Alto del Pesebre sector, Tama National Natural Park, Colombia.

Our record adds one new specimen to the species collection after at least 100 years, highlighting the survival of the species on the Tama massif. Although this record is not remarkable in terms of range or elevational extension, given the scarcity of information and even specimens, we considered this a noteworthy addition to the already scarce species knowledge, especially by confirming still its presence in Colombia after a century.

Despite the importance of the Tama massif, there is a remarkable generalized lack of knowledge of most species in the area (Cáceres-Martinez et al., 2016), and recent assessments have highlighted the recent advance of multiple threats from hunting to habitat loss, risking this unique region (Cáceres-Martínez etr al., 2014; Cáceres-Martínez et al., 2016). Our record provides further support for the urgent need of comprehensive conservation management of the area and especially further study of most biological groups in the massif.

\section{Acknowledgements}

We thank the Foundation Alejandro Angel Escobar (FAAE), Idea Wild, Parques Nacionales Naturales de Colombia, vicerrectorías Académica y de Investigaciones, Universidad de Pamplona. To the Universidad de Antioquia mammal collection for support on the species identification.

\section{References}

ACEVEDO, A., et al. 2016. Diversity of Andean amphibians of the Tamá National Natural Park in Colombia: a survey for the presence of Batrachochytrium dendrobatidis. Animal biodiversity and conservation 39(1): 1-10.

CÁCERES-MARTÍNEZ, C. H., et al. 2015. Registros plásticos en la ingesta de Tremarctos ornauts (Carnivora: Ursidae) y de Nasuella olivacea (Carnivora: Procyonidae) en el Parque Nacional Natural Tamá Colombia. Revista Mexicana de Biodiversidad 86(3): 839-842.

CÁCERES-MARTÍNEZ, C. H., et al. 2016. Terrestrial medium and large-sized mammal's diversity and activity pattems from Tamá National Natural Park and buffer zone, Colombia. Therya 7(2): 285-398.

GARCÍA, F. J., et al. 2014. Variación intraespecífica en Cryptotis aroensis (Mammalia, Soricomorpha, Soricidae) de Venezuela. Therya 5(2): 589-600.

MINAMBIENTE. 2008. Parque Nacional Natural Tamá: Plan de manejo 2006 - 2010. Documento ejecutivo. Ministerio de Ambiente, Vivienda y Desarrollo Territorial, Unidad Administrativa Especial del Sistema de Parques Nacionales Naturales, Dirección Territorial Norandina. Bucaramanga, 30 pp.

QUIROGA-CARMONA, M., \& J. MOLINARI. 2012. Description of a new shrew of the genus Cryptotis (Mammalia: Soricomorpha: Soricidae) from the Sierra de Aroa, an isolated mountain range in northwestern Venezuela, with remarks on biogeography and conservation. Zootaxa 3441: 1-20.

QUIROGA-CARMONA, M. 2013. Una nueva especie de musaraña del género Cryptotis (Soricomorpha: Soricidae) de la Serranía del Litoral en el norte de Venezuela. Mastozoología neotropical 20(1): 123-137.

QUIROGA-CARMONA, M., \& N. WOODMAN. 2015. A new species of Cryptotis (Mammalia, Eulipotyphla, Soricidae) from the Sierra de Perijá, Venezuelan-Colombian Andes. Journal of Mammalogy 96(4): 800-809.

WOODMAN, N. 2002. A new species of small-eared shrew from Colombia and Venezuela (Mammalia: Soricomorpha: Soricidae: Genus Cyptotis). Proceedings-Biological Society of Washington 115(2): 249-272.

WOODMAN, N. 2008. Cryptotis tamensis. The IUCN Red List of Threatened Species 2008: e.T136780A4338950.

\section{Mammalogy Notes | Notas Mastozoológicas \\ Sociedad Colombiana de Mastozoología \\ Vol. 4 Num. 1| 2017}

